\title{
OA07.03. Randomized, double-blind, double- dummy trial of myrrh, chamomile, coffee charcoal compared to mesalazine in maintaining remission in ulcerative colitis
}

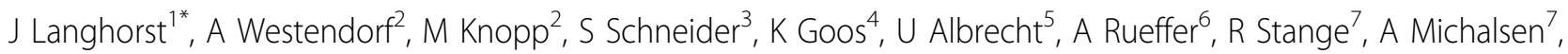 \\ G Dobos'
}

From International Research Congress on Integrative Medicine and Health 2012

Portland, Oregon, USA. 15-18 May 2012

\section{Purpose}

We compared the efficacy of the herbal preparation of myrrh, chamomile extract and coffee charcoal (herb) with a mesalazine (mes) therapy in maintaining remission in ulcerative colitis (UC).

\section{Methods}

A total of 96 patients (51 female) with UC in remission (not longer than 12 months) were included in a randomized, double-blind, double-dummy, multicenter, non inferiority study comparing mesalazine $500 \mathrm{mg}(3 \times 1 / \mathrm{d})$ to $100 \mathrm{mg}$ myrrh, $70 \mathrm{mg}$ chamomile extract and $50 \mathrm{mg}$ coffee charcoal $(3 \times 4 / d)$ over a time period of 12 months. As primary outcome criterion, non-inferiority of the herbal preparation was defined and accepted, if the difference in the colitis activity index (Colitis Activity Index - CAI - Rachmilewitz) (calculated at six time points during the 12 month interval) averaged over all visits was $\leq 1$ point. Furthermore, relapse rates, relapse-free times, safety, a comprehensive activity index (CAI, CRP and fecal Lactoferrin, Calprotectin and PMN-Elastasis), an endoscopic activity index and Health-related Quality of life (HrQoL) were assessed. Peripheral CD4+CD25+ reg T-cells were investigated in a subgroup at each time point and during a flare.

\section{Results}

Primary outcome criterion $(\mathrm{p}=0.19)$, relapse rates $(\mathrm{CAI}>4)$ (mes 22/49 patients vs herb 25/47 patients; $\mathrm{p}=$

'University of Duisburg, Complementary and Integrative Medicine, Essen, Germany

Full list of author information is available at the end of the article
0.54), relapse-free time (268 \pm 22 days for mes and $240 \pm$ 23 days $(\mathrm{p}=0.40)$ for the herb), the comprehensive activity index and HrQoL did not show a significant difference. Of notice, peripheral CD4+CD25+ regulatory Tcells showed a distinct different pattern at time points pre-flare and flare for the two treatment modalities (CD4 $+\mathrm{CD} 25+\mathrm{T}_{\text {reg }}$ mes $\mathrm{p}=$ non significant $(\mathrm{ns})$; herb $\mathrm{p}=0.02$; $\mathrm{CD} 4+\mathrm{CD} 25+\mathrm{T}_{\text {reg }}$ high mes $\mathrm{p}=\mathrm{ns}$; herb $\left.\mathrm{p}=0.008\right)$.

\section{Conclusion}

The herbal preparation shows efficacy and safety in maintaining remission non-inferior to mesalazine in ulcerative colitis. It appears to offer an alternative option for maintenance therapy. Regulatory T-cell pattern might give first evidence to suggest a different mechanism of action.

\section{Author details}

${ }^{1}$ University of Duisburg, Complementary and Integrative Medicine, Essen, Germany. ${ }^{2}$ Department for Microbiology, University of Duisburg-Essen, Essen, Germany. ${ }^{3}$ Biometric Institute, University of Hannover, Hannover, Germany. ${ }^{4}$ Repha GmbH, Hannover, Germany. ${ }^{5}$ Mediconomics, Hannover, Germany. ${ }^{6}$ Enterosan, L+S Labor, Bad Bocklet - Grossenbrach, Germany. ${ }^{7}$ Immanuel Hospital, Charité, Berlin, Germany.

Published: 12 June 2012

doi:10.1186/1472-6882-12-S1-027

Cite this article as: Langhorst et al:: OA07.03. Randomized, double-blind, double-dummy trial of myrrh, chamomile, coffee charcoal compared to mesalazine in maintaining remission in ulcerative colitis. $B M C$ Complementary and Alternative Medicine 2012 12(Suppl 1):O27.

\section{C) Biomed Central}

(c) 2012 Langhorst et al; licensee BioMed Central Ltd. This is an Open Access article distributed under the terms of the Creative Commons Attribution License (http://creativecommons.org/licenses/by/2.0), which permits unrestricted use, distribution, and reproduction in any medium, provided the original work is properly cited. 